\title{
Korea's Role for Peacebuilding and Development in Asia
}

\author{
Brendan M. Howe
}

South Korea (Korea) lacks the compulsory power of regional and global great powers, but still strives to play a major role in the fields of peacebuilding and development. It is a middle power which, due to geopolitical constraints, is unable to play the neutral or brokering role of traditional middle powers, and thus must turn to other areas of agenda setting and niche diplomacy. This article examines policy arenas for which Korea is particularly well suited to playing such a role, and in which Korea can have a major impact, significantly to the mutual advantage of Korea and its regional partners. In order to do so to the best of its ability, Korea needs to shift its policy emphasis from bilateral to multilateral endeavors.

Keywords middle power, niche diplomacy, official development assistance (ODA), peacekeeping operations (PKOs), humanitarian assistance

\section{Introduction}

By many indicators (military expenditure, economic, population, etc.) the Republic of Korea (hereinafter Korea or the ROK) has long been a middle power, resting somewhere between the global and regional behemoths, and the small powers who, according to the doctrines of realpolitik, "suffer what they must." While according to any of these measurements, but in particular economic and military ones where Korea is certainly not in the middle of the pack but rather would be counted towards the upper end of such rankings, this article argues that the nature of Korea's power, and the way it is manifested, places it below those "great" powers which have the capacity to affect international affairs across all realms of interaction and geographical locations, and above "small" powers which have little or no impact on international interactions.

The notions of what it is to be a middle power and how power is measured are, however, in of themselves, somewhat challenging to define. Ashley Tellis et al. (2000) note that although the notion of "power" underlies most analyses of 
politics, it remains one of the most contested concepts in the social sciences. Yet despite the apparently wide variety of definitions and usages, most notions of power boil down to references to "allocation of resources," "ability to use these resources," and the "strategic character" of power, meaning its use not only against inertia, but also opposing wills. "This tripartite approach to power can be restated using a simple taxonomy that describes power as 'resources', as 'strategies', and as 'outcomes'" (ibid., 13-14). Thus, a middle power is one that has somewhat middling access to resources, pursues strategies appropriate to middle-powerism, and/or has a modest ability to impact the external operating environment.

The starting point for the first of these concepts, access to resources, is power base theory. That is to say, what criteria are to be used for measuring the power of states, and the theoretical justification for assessing those, rather than other, components? The problems here break down into (1) delimitation, or which variables to use, (2) aggregation, or how to combine them, and (3) salience of particular variables over time. Proponents of long cycle theory, for instance, rely on analysis of changes in the concentration of sea power/global reach capability. With the rise of importance of aircraft carriers in this reckoning, this would give a break-down of one superpower (the United States), perhaps four great powers (China, France, Russia, and the United Kingdom), and everybody else somewhere below. Other single-variable indicators of power have included military personnel, military expenditure, and national income. Worries over the "realism" of single-variable analysis, and changing salience, has led other authors to include different measurements and combinations of power. Most include some measurement of land area, population, industrial/economic capability, and military might.

Wilhelm Fucks constructed three power indices: the first based on steel production and population, the second based on energy production and population, and the third based on an average of the previous two indices (Heiss, Knorr, and Morgenstern 1973, 30-47). For Ray Cline (1997, 34), Perceived Power (Pp) is a function of Critical Mass ( $\mathrm{C}=$ Population + Territory), Economic Capability (E), Military Capability (M), Strategic Purpose (S), and Will to Pursue National Strategy $(\mathrm{W})$, where $\mathrm{Pp}=(\mathrm{C}+\mathrm{E}+\mathrm{M})(\mathrm{S}+\mathrm{W})$. David Singer's is the most popular multivariate analysis of power due to its association with the mammoth Correlates of War project. It has three dimensions of capability divided into six variables: demographics [total population; urban population (cities of 20,000 or larger)]; industrial capability [energy consumption; iron and steel production]; and military [expenditure; personnel] (Singer and Diehl 1990). These measurements would most likely result in the United States, China, Russia, the United Kingdom, France, Germany, Japan, India, and perhaps Brazil as being perceived as great powers, with other notable powers such as Korea, Australia, Italy, and Canada being assessed as middle powers.

Finally, F. Clifford German felt that the impact of nuclear weapons was such 
as to essentially divide the world into nuclear and non-nuclear powers, where national power $(\mathrm{G})$ was a function of nuclear capability $(\mathrm{N})$, land $(\mathrm{L})$, population $(\mathrm{P})$, industrial base (I) and military size (M), and where $\mathrm{G}=\mathrm{N}(\mathrm{L}+\mathrm{P}+\mathrm{I}+\mathrm{M})$ (Stoll and Ware 1989, 19). Thus nuclear powers would be considered great powers, whereas non-nuclear powers can, at best, aspire to middle-powerism. In addition to the "P5," Permanent Members of the United Nations (UN) Security Council, this would place North Korea as a great power, along with India, Pakistan, Israel, and potentially South Africa, Iran, and the former Soviet states of Belarus, Kazakhstan, and Ukraine. Yet the likes of Australia, Brazil, Japan, South Korea, and Germany would be considered as of a lesser ranking. Measurement and aggregation of these variables is thus extremely controversial.

Singer's formula is perhaps the simplest as it involves adding up the world's total on each dimension and then expressing a particular nation-state's value as a percentage of the world total, then averaging each nation-state's scores on the six dimensions to obtain its composite score (ibid., 16). While very elegant, Singer's method has attracted a great deal of criticism with regard to its equal weight aggregation. It is also considered particularly vulnerable to changes in salience. Other approaches, therefore, have attempted to find more accurate (if more complicated) aggregation equations. Each of these, however, introduces greater subjectivity into the measurement, as different aggregation models are essentially "eyeballed" for best fit. No formula for measurement or aggregation provides a perfect picture of state power, and no matter how accurate its initial findings, all decay over time due to technological change. Hence Tellis et al. (2000, 3031) claim that "since the 1970s, no new attempts at developing aggregate power measurements of the kinds illustrated above have materialized (or at least none have received widespread visibility)."

Perhaps not surprisingly, therefore, these different measurements have thrown up different lists of those countries which qualify as being "great" powers and, consequently, those that may therefore be seen as "middle" powers at any particular chronological moment. Sometimes there has been formal recognition of great powers at an international level, such as during the nineteenth century "Concert of Europe" which was established by the peace of Vienna ending the Napoleonic Wars, under the UN system with the Security Council's P5, or in accordance with the G7 or (now defunct) G8 group of leading economic powers. Other important states not so recognized could conceivably be considered as middle powers.

The problem then rests with the powers which are not included in the great power categorization, but by some measures have access to resources of equal or greater magnitude to those already listed as such. Hence the push for expansion of the P5 to include the G4 countries, Brazil, Germany, India, and Japan, the move from G7 to G8 to include Russia, and the inclusion of the European Union (EU) as an entity distinct from its component parts in various international fora. 
If we look at the most recent incarnation of a global governance organization, the Group of Twenty (G20), Colin Bradford $(2015,9)$ has identified the great powers represented there as being China, the EU, Russia, and the United States; with Australia, India, Indonesia, Japan, and South Korea providing Asian regional middle power representation.

Thus, if we rely simply on the greatness of access to resources, or international recognition thereof, the dichotomy between great and middle powers may be considered an essentially contested concept. Is Japan, for instance, a great power or a middle power according to these measurements? Kent Calder (1998), the originator of the "reactive state" hypothesis, downgrades Japan even further than middle power status, seeing the country as occupying the unique position of having the power potential of a mid-range European state, yet the political leverage of much smaller and weaker reactive states. Calder (ibid., 518-528) claims that the fragmented character of state authority in Japan makes decisive action more difficult than in countries with strong chief executives, such as the United States, thereby explaining Japanese passivity in international affairs when activism would have been both possible and beneficial for Japan.

This article, therefore, looks at the other two elements implied by Tellis et al. (2000): whether a particular state (in this case Korea) has the potential for a "middling" impact on international affairs, and whether it pursues strategies appropriate to "middle-powerism." Middle powers lack "compulsory power," the military resources to dominate other countries or the economic resources to bribe countries into adopting policies that they would not otherwise pursue. Yet they differ from the small or "system ineffectual" states which have little or no influence. They are, potentially, "system affecting states" which can have a significant impact within a narrower policy area, or in conjunction with others (vom Haua et al. 2012, 187-188). As such, to maximize their relevance and impact, a degree of selectivity on the part of these middle powers is required, in terms of policy prioritization and/or geographical region. This means the pursuit of "niche diplomacy" (as identified by Gareth Evans, the former Australian foreign minister, and founder of International Crisis Group), which involves concentrating resources in specific areas best able to generate returns worth having, rather than trying to cover the field, allowing them, therefore, to "punch above their weight" (Henrikson 2005, 67).

Middle power activism is all about visibility on the international stage, but also concerns playing by the rules of the global normative consensus, and demonstrating a willingness to be a good global citizen. Thus, conference diplomacy and agenda-setting is also vital to the role played by middle powers. The tools of middle powers, therefore, include agenda-setting, coalition-building, and public diplomacy in order to affect the international system and strategic operating environment. Yet it is only fairly recently that Korea has engaged in middle power activism, and put together something like a coherent public 
diplomacy strategy, officially endorsing the concept only in 2010 (Ma, Song, and Moore 2012). The Act on Public Diplomacy, which passed the National Assembly's Foreign Affairs and Unification Committee in November 2015, did not come into effect until August 2016 (MOFA 2016).

That being said, long before the ROK officially endorsed and started to promote its interests through public diplomacy, Seoul was engaged in numerous other practices which helped serve similar agenda-setting and reputationbuilding purposes. These have revolved around the related soft power and niche diplomatic areas of development and development assistance, disaster and humanitarian relief, as well as peacekeeping operations and peacebuilding initiatives. While the ROK's role in these areas may well reflect the country's strategic national interest, rather than being motivated solely by humanitarian concerns, this can ensure greater commitment and impact in the region.

Furthermore, these are areas of potential collaboration with other regional actors, both great and middle powers, who perhaps share Korea's outlook and policy prioritization, but are currently in conflictual relationships with each other and with the ROK. Not only, therefore, does this open the possibility of trustbuilding through cooperation among these actors, but also reflects what Brian Hocking $(2005,29)$ has identified as a new "network" model of diplomacy, in which "empowered by the resources provided by the CIT revolution... [publics] are direct participants in the shaping of international policy and, through an emergent global civil society, may operate through or independently of national governments." According to Seungjoo Lee (2014, 2-3), contemporary global politics as a whole is organized in a networked fashion rather than in accordance with a power hierarchy. Thus, middle powers like Korea are able to increase their visibility and influence (and therefore effective public diplomacy), even if they are not equipped with the material power to dictate. Lee further identifies circumstances under which middle powers are better positioned between various players (great and small powers, international organizations and NGOs, etc.) to take advantage of their positions within the complex network.

This article, therefore, looks at the potential impact of ROK middle power activism across a range of related roles in the peacebuilding and humanitarian spectrum. These include agenda setting and paradigm creation as a postconflict development success story worthy of emulation; direct experiential and knowledge transference; official development assistance (ODA); humanitarian assistance; peacekeeping operations (PKOs); and potential collaboration with other East Asian actors. Together, these contributions amount to a significant regional and even a global role for a middle power in terms of peacebuilding and development. In addition, the rapidly shifting nature of peace-building and development cooperation in the twenty-first century presents middle powers with a "noble opportunity" to do something that is both normatively right and beneficial to others, while also in the national interest; and these changes have 
coincided with "South Korea's ambitious launch of its middle power diplomacy strategy" (ibid.).

\section{A Paradigmatic Success Story?}

Perhaps the "purest" way a middle power can have a major influence on others without resorting to either coercion or inducements is through attraction to what the middle power represents, or what it has achieved. This is related to the concept of "soft power" which Joseph Nye (1990; 2004) claims is not only more legitimate than coercion or bribery, but also can be exerted by those less wellendowed with the traditional resources of hard power. Furthermore, the central precepts of the concept of democracy by convergence demonstrate "how an almost universal wish to imitate a way of life associated with the liberal capitalist democracies of the core regions (the wish for modernity) may undermine the social and institutional foundations of any regime perceived as incompatible with these aspirations" (Whitehead 1996, 21).

Thus, assuming Korea represents a "shining city on the hill" in terms of successful economic and political development, which others feel worthy of emulation, Korea can provide a stimulus not only for development in neighboring countries, but also for peacebuilding through the facilitation of a "democratic contagion" and the proliferation of democratic dyads less likely to go to war with one another than any other pairs of states. In particular, the extent to which Korea can be seen as a paradigmatic case study of the successful utilization of international assistance in the economic and security fields holds important implications for peacebuilding and development in East Asia and beyond.

After the Korean War (1950-1953), the ROK was utterly devastated politically, economically, and socially. "Not only did the war render most of the infrastructure and production facilities inoperable, but it also all but decimated the state's capacity to govern," and Korea thus faced the dual challenge encountered by many post-conflict societies of economic reconstruction and governance reconstitution (Suh and Kim 2014, 53). "Unlike most that fall under the weight of the burden, however, Korea successfully rose to the challenge to transform itself from a war-torn to an industrialized country" (ibid.).

Ranging from emergency relief to structural adjustment programs, ODA significantly contributed to Korea's own economic and social development. In particular, ODA was the only available source of capital following the devastation of the ROK's economy by the Korean War. From 1945 to the early 1990s, Korea received ODA from other countries that amounted to a total of \$12 billion (ODA Korea 2013). During the period of rapid economic growth from 1961 to 1975, more concessional loans and other forms of financial investment came to Korea, allowing it to build social and economic infrastructure and promote industrial 
development. The "miracle on the Han River" saw Korea grow from one of the world's poorest countries, with a GDP per capita of $\$ 67$ in 1953, to the world's thirteenth-largest economy. Korea's economic growth can thus be seen, to a certain extent, as having been fueled by foreign aid. In particular, beginning in the 1960s, ODA provided to Korea acted like domestic capital, allowing the Korean government to utilize the funds to support its industrial policies (Kim 1997).

Korea retained ownership of their ODA recipient experience, sometimes against the wishes of the donor, something which has now become standard operating procedure for development partnerships, but was unusual at the time. Perhaps more important was the prioritization of human capacity-building and education in the ROK. In fact, economic growth and human capacitybuilding have interacted throughout the history of Korea's attempt to escape the transformation trap, and both donor and government-led economic development plans have been directly reflected in education policy and planning (Lee 1997). Despite financial limitations, the Korean government initiated a "national campaign for literacy," contributing to an increase in the adult literacy rate from 22 percent in 1945 to approximately 80 percent in 1960 (Pillay 2010, 10). Since the 1960s, the government has focused on providing an education system based on the needs of human resources (ibid., 73). The focus of the government's educational plan has moved from primary to secondary education and finally to the tertiary level, according to its economic advancement (Lee 1997). Consequently, Korea has achieved the largest increase in human capital stock. The average years of schooling of the population aged 15 and above more than doubled from 4.2 years in 1960 to 9.9 years in 1990, which exceeds the average of the Organisation for Economic Co-operation and Development (OECD) countries as a whole (ibid.).

In 1995, Korea graduated from being an aid recipient when it paid off its final structural adjustment loan to the World Bank. It was removed from the OECD's list of recipient nations in 2000, and ultimately became the newest member of the OECD Development Assistance Committee (DAC), and host of both the G20 and the High Level Forum (HLF-4) on Aid Effectiveness. A second, political, miracle on the Han has seen the ROK successfully transition to, and then consolidate as, a representative liberal democracy. To a certain extent, therefore, the ROK does represent a rare case of an ODA recipient success story: a country that has overcome the dual challenges of post-conflict underdevelopment and insecurity, a "miracle" of economic and political governance development, and a country that embraces both macro and human-centered development in its policy prioritization.

There remain, however, caveats concerning this performance. Macroeconomic models and measurements detailing the "Miracle on the Han River" do not take sufficient account of the distribution of economic wellbeing. While 
rapid economic development lifted many out of poverty, and in the early decades of growth these economic benefits were relatively equitably distributed, this began to change in the mid-1990s. The major turning point was the 1997 Asian financial crisis which had devastating consequences for the economy and for the livelihoods of the working population. Hagen Koo (2014) has pointed out that the consequences of the financial crisis were uneven, with the most vulnerable bearing the brunt of the downturn. "While the majority of working people suffered tremendously, those who possessed financial resources took advantage of credit-scarce market conditions and came out of the crisis richer than before." As a result, economic inequality increased noticeably during and after the crisis, with Korea's Gini coefficient (the most commonly used measurement of inequality) rising from an average of 0.258 for 1990-1995 to 0.298 in 1999, two years after the onset of the financial crisis. It continued to increase, reaching 0.315 in 2010, placing Korea still in the middle of pack in terms of economic inequality, but in a steadily worsening position (ibid.).

Meanwhile, the Act on Assembly and Demonstration requires police permission to be obtained before holding any assembly or demonstration. Without such permission, individuals exercising their constitutional rights are considered to be participating in illegal acts (Ney 2008). Thus, according to the 2015 International Trade Union Congress (ITUC) Global Rights Index, the Republic of Korea ranked among the world's worst countries for workers, with "no guarantee of rights" (ITUC 2015, 12). Since the ITUC report, the government and the courts have further assailed the rights to freedom of peaceful assembly and of association among workers, and thereby their ability to facilitate a distributive justice transformation. As a result of such measures, in a statement at the conclusion of his visit to the ROK, Mr. Maina Kiai, the United Nations Special Rapporteur, noted a "trend of gradual regression on the rights to freedom of peaceful assembly and of association... a slow, creeping inclination to degrade them" (Kiai 2016). He further pointed out that "even the courts which should always interpret laws in favor of rights have recently been moving towards restricting rights rather than expanding them."

Indeed, there are growing concerns about the nature of Korean democratic transition and consolidation. The ROK is, in fact, a prime example of a Schumpeterian elite model of democracy. Governance by elites is simply not good enough, as elites are predisposed to look after their own interests first, even at the expense of other members of the demos. Worse, elite domination (and the corresponding disenfranchisement of other groups) has grown in recent years, facilitated by econophoria, slavish adherence to neoliberal principles, and the policy-making of successive conservative administrations. Elites have captured the commanding heights of industry, governance, legislation, administration, prosecution, education, and communication. As a result, corruption (and the perception thereof) has grown, and the voice of the demos has been diminished, 
along with trust in the instruments of governance. The lack of trust in regular political processes was highlighted from October 2016 to March 2017, with successive weeks of demonstrations in Seoul and throughout Korea, featuring hundreds of thousands of protestors calling for the removal of President Park Guen-hye.

Nevertheless, the protests themselves can be seen as robust engagement of the Korean public defending their hard-won democratic rights. They were ultimately successful, leading to the removal of a delegitimized President and her regime through the legitimate means of impeachment, new democratic elections, and the ongoing trials of members of the elite, including for President Park and the acting head of Samsung (the county's largest business conglomerate). Park's closest confidant, Choi Soon-sil, has already been convicted and imprisoned. This robust democratic engagement can also serve as an example and inspire others to defend their rights. As such, it is still possible that the ROK can act as a "shining city on the hill" while agenda setting on the wider international stage.

Not content with this passive role, however, successive administrations in Seoul have looked to an active promotion of the Korean "way," and also to contribute to the development of others in order to facilitate peaceful relations.

\section{The Korean Model}

Economic development has long been held as conducive to both democratization and peacebuilding. Domestically, economic development is seen to boost the growth of civil society which in turn pressures the government to make political reforms. Internationally, through the promotion of interdependence, economic development increases the costs of war and decreases the hoped for benefits. At both the domestic and international levels, commentators such as Ernst Haas (1964) and David Mitrany (1976) have noted how cooperation in the "low" political arenas such as economic, social, technical, humanitarian, prosperity, welfare, and social justice promotion can spill over into the "high" political areas of peace and security. This formed the basis of the European integration project, and is also official doctrine in the UN where such activities are undertaken for the sake of the indirect contributions which they make to solve the problems of peace and security. If they are useful in themselves, so much the better. Thus, this section assesses the degree to which Korean assistance can stimulate development in other countries, and also be seen to be doing so.

Korea sees its own experience as an asset it can provide to other recipients of aid. As such, Seoul has sought to export its lessons learned rather than be content to serve merely as a developmental shining city on the hill, enhancing the country's visibility while making a unique contribution (Chun, Munyi, and Lee 2010, 798). Hence, "in search of a new, responsible global role in the twenty- 
first century, the Korean government has announced that it will provide foreign aid with a 'South Korean Model of Development Cooperation' based upon its 'development experience' in the latter half of the twentieth century" (Kim, Kim, and Kim 2013, 314).

As early as 1977, the Ministry of Foreign Affairs and Trade of Korea (MOFAT) started providing technical cooperation to a number of developing countries (Chun et al. 2010, 790). Seoul has launched three major policy platforms. First, the Knowledge Sharing Program (KSP), which was launched in 2004, is advertised as a "new paradigm of development cooperation" and a "knowledgeintensive development and economic cooperation program designed to share Korea's development experience with partner countries" (KSP 2013). Second, the Development Experience Exchange Program (DEEP), run by the Korean Overseas International Cooperation Agency (KOICA), is based on knowledge transfer of Korean expertise and experience (including two decades of KOICA ODA activities), and also looks to provide a dynamic transition model tailored to the specific needs of individual development partners and their operating environments (Lee 2014, 18). And third, the World Friends Korea volunteer organization seeks "to improve the quality of life of residents in developing countries; to increase cooperation and mutual understanding between developing countries and Korea; [and] to achieve self-realization and growth through service activities" (World Friends Korea 2016). The ROK is one of only six countries that has such an overseas volunteer program (the others are Belgium, Germany, Japan, Luxembourg, and the United States), and Korea's program is second only to the United States' in terms of size (Roehrig 2013, 632).

It is perhaps not surprising, given Korea's own success, that economic development has played a central role in policy initiatives aimed at influencing global discourse and the international governance agenda, reflecting both national interest and an operational niche within which Korea can punch above its weight. In recent years, the most prominent of these initiatives has been the "Global Korea" agenda pursued by the Lee Myung-bak administration, the aims of which included being "a global actor with broad horizons that engages proactively with the international community in the service of peace and development in the world," and a state which "should seek the attributes of a soft, strong power as it builds up its capacities to become a global actor" (Office of the President 2009, 12-13).

Olbrich and Shim $(2012,2)$ see the Global Korea strategy as embodying "South Korea's global ambitions in development and security" as well as bolstering its international influence and reputation. Kalinwoski and Cho $(2012,243)$ have noted how under the guise of the Global Korea strategy the Lee Myung-bak administration further prioritized the economic realm in Korean foreign policy, with Korea seeking to turn its economic success story into a political asset, and using its increasing economic clout to expand into global politics in order to 
protect and facilitate its economic interests abroad. This policy had a significant pre-history, however, in the resource diplomacy of the preceding liberal Roh Moo-hyun administration. Thus, the central role of economic development in Korean international policy-making is an area of remarkable consensus.

In accordance with its new DAC responsibilities, Korea is looking to dramatically expand its ODA budget and also to host many fact-finding missions and students from small and medium-sized regional economies who see in the ROK a role model more closely analogous to their own conditions and experiences than perhaps is the case with more traditional donors. Furthermore, Korea is unique among donors in not suffering from any neo-imperial baggage. Thus, for Soyeun Kim $(2011,805)$, "the Korean ODA model in particular epitomises Seoul's strategic positioning (or bridging) between the developed and developing countries. With the model, Korea promotes its distinctive approach to aid while at the same time proclaiming its willingness to be part of global aid efforts."

According to Watson (2013, 234), "for the South Korean government, by linking its foreign aid with South Korean corporations, the activities reflect the soft power of the government as 'national brand." Likewise, for The Economist (2012), while interest in the Korean model of economic success has been around for a while, "what has changed in recent years is the government's willingness to promote the success, and the increasing number of newly developing countries that want to learn from it." Both Brand Korea and attempts by the ROK government to promote it are in fact multi-faceted. The Presidential Council on Nation Branding (PCNB) has in fact set out five priority areas, aimed at proactively promoting Korea to move away from its perceived periphery image within global society and, in combination with "contribution diplomacy," "aims to promote Seoul's leadership in tackling global issues such as climate change and poverty reduction through its ODA" (Kim 2011, 810).

Even before joining the OECD DAC, "Korea had emerged as the unrivalled leading donor, in absolute amounts, among non-DAC OECD countries" (Chun et al. 2010, 790). By the time of the first DAC peer review of Korea in 2012, the country had trebled its ODA over the preceding five years to $\$ 1,325$ million per year, or 0.12 percent of its gross national income (GNI), and it had committed to a further doubling by 2015 (OECD 2012). In 2012, Korea's ODA amounted to $\$ 1,597.5$ million (net disbursement), of which $\$ 1,183.2$ million was bilateral aid and $\$ 414.3$ million was multilateral aid. Grants amounted to $\$ 714.9$ million (60.4 percent) and loans to $\$ 468.3$ million (39.6 percent) of the total; KOICA provided $\$ 444.5$ million the same year (ODA Korea 2014). In fact, in 2012, under conditions of financial crisis, Korea had the largest increase in ODA among the DAC at 17 percent, far ahead of Australia's 9.2 percent, the next largest increase; most DAC members decreased their ODA that year (Roehrig 2013).

Again, however, we must be aware of caveats regarding Korean international 
assistance, and the reception it receives internationally in terms of serving as a useful area of niche diplomacy. For a start, it is far from certain that Korea's ODA recipient experience can or should be replicated. The first period of development assistance to Korea was boosted by the presence of an occupying power that provided most of the grants. The second was characterized primarily by grants and unconditional ODA, the relative absence of which in Korea's own assistance programs has led to international criticism. The third depended not only on reparations from the former colonial power, but also from the tremendous boost the Korean economy received from U.S. involvement in wars in Southeast Asia. The fourth saw political transformation and consolidation as a democracy, but as explored above, the foundation of future governance includes challenges. The fifth witnessed ongoing economic transformation, including the weathering of the Asian financial crises storm, and the adoption of International Monetary Fund (IMF) prescriptions with regard to market opening and neoliberal reforms, all of which have posed additional challenges to the wellbeing of vulnerable groups in the ROK.

The Korean emphasis on education in the country's own development, and in its knowledge sharing and ODA is potentially problematic. Education has always held a privileged position in Korean society. Other societies may not be able to manufacture such dedication to and respect for education. Furthermore, there have been some negative impacts of this focus in the ROK. The concentration of public and private funds on education leaves less for other human needs. There is an inflation of academic qualifications, while a scarcity of practical skills. Finally, educational competition has increased the strain on society, on students, on their families, and on academics. Even the overt use of the term "Korean Model of Development" has been criticized as implying “one size fits all'-a singular mode of development-which does not fit with the global norms on foreign aid and development cooperation that recognize diverse developmental contexts of recipient nations" (Kim et al. 2013, 315). By placing an emphasis on the Korean model, there is a risk that Seoul's policies will be viewed as self-centered and derived from overconfidence in the country's own development success, and it might be "received as arrogance unless carefully executed" (Chun et al. 2010, 799).

Korea has been further criticized not only for its relatively low level of ODA as a proportion of gross domestic product (GDP), but also for high levels of tied aid. Korean aid topped only $\$ 500$ million in the mid-2000s, and although it reached $\$ 1.325$ billion in 2011 , this was only equivalent to 0.12 percent of its GNI (OECD 2012). Korea's ODA volume in 2011 was 6 percent greater than in 2010, but when its aid surpassed \$1 billion for the first time, its ODA/GNI ratio was unchanged from 2010 and below DAC members' average of 0.32 percent as well as its target of 0.13 percent for the year. Korea committed to increase the total volume of ODA to about $\$ 3$ billion and ODA/GNI to 0.25 percent by 2015 , but 
this has not been achieved. Korea's total volume of ODA and its ODA/GNI ratio remain relatively small when compared with other traditional donor countries in North America, Western Europe, and, in particular, the Nordic countries. Indeed, Korea has been ranked at or near the bottom of many quantitative measurements of ODA among DAC member countries. These include total ODA, ODA/GNI ratio, bilateral aid/ODA ratio, grants/ODA ratio, humanitarian grants/ODA ratio, multilateral aid/ODA ratio, and the Commitment to Development Index, comprising the seven areas of aid, trade, investment, technology, environment, migration, and security (Choi 2010, 42; Lee 2012, 977; Lee 2014, 41; Park 2014, 2).

Historically, much of Korea's aid has been tied, or given on condition that it be spent on goods or services provided by Korean interests. In 2006, as much as 98 percent of the ROK's aid was estimated as being tied or partially tied (Kalinowski and Cho 2012, 249). In 2007, some progress appeared to have been made, with as much as 25 percent of Korean aid being untied, but this was still well below the OECD DAC member average (Park 2010). Consequently, as "part of its accession to the DAC and its commitment to the Paris Declaration principles and the Accra Agenda for Action, in 2009 Korea put a timetable in place to increase the untied portion of its bilateral ODA to 75 percent by 2015" (OECD 2012, 20). By the time of the OECD DAC peer review in 2012, however, it was noted that Korea had in fact made no progress towards this aim, but rather, "the untied proportion of Korea's total aid was lower in 2010 (at 32 percent) than in 2009 (44 percent)" (ibid.).

Finally, Korea has been criticized for focusing too greatly on bilateral rather than multilateral assistance (Kalinowski and Cho 2012, 249). Given that from one perspective, middle-power activism is all about visibility on the international stage, it is not surprising that Korea clings to bilateralism rather than multilateralism: when ODA is distributed by one single international organization, the visibility of the individual provider nation is reduced, which contradicts the aims of the Global Korea strategy (Olbrich and Shim 2012, 4). International guidelines for aid effectiveness, such as the Paris and Accra road maps, recommend multilateral approaches, but considering the more than thirty donors per recipient country and the strong competition for recognition this entails, Korea is likely, from its strategic perspective, predominantly to continue to go it alone.

Yet such focus on bilateral strategic relationships over multilateral collective efforts related to the global commons contradicts contemporary conceptions of successful middle powers, particularly in terms of agenda setting and reputation building. For instance, it is perceived that the factors behind recent ROK involvement in sub-Saharan Africa are the pursuit of Korean food and energy security; the establishment of new markets for its manufactured goods; and strategic competition with other East Asian actors, particularly China, in a new "scramble for Africa" (Darracq and Neville 2014, 2-3). Korean government and media outlets also tend to present developing nations as either charitable objects 
or new economic frontiers, which leads critics to argue that such behavior goes against "Seoul's much-heralded moral obligation to voluntarily fulfill universal norms and values of liberty, justice, and humanitarianism/benevolence" (Kim 2011, 811). Middle powers need to go beyond narrowly defined national interests to accommodate other actors' interests "to organize the global governance of development cooperation by linking multiple fora" (Lee 2014, 3).

"Middle power states have most recently been defined by their internationalism. States that exhibit certain foreign policy behavior are considered middle powers. Qualifying behavior might include good 'global citizenship', niche diplomacy, and accepting roles as mediators, followers, or staunch multilateralists" (Rudderham 2008 , 2). From this perspective, status as a middle power is conferred in accordance with behavior rather than size. Middle-power activism is all about visibility on the international stage, but it is also about playing by the rules of the global normative consensus and demonstrating a willingness to be a good global citizen. Although not as developed an area of Korean policy-making, collaborative middle-power activism perhaps holds even greater promise of benefit to both the ROK and to other countries.

\section{Multilateral Middle-Powerism}

This realm is, in fact, one area where Korean ODA has already garnered significant international recognition and plaudits. At the G20 Seoul Summit, much was made of the concept of Korea serving as a bridge between the developing and developed worlds as a result of its own experience and expertise, and the forum offered Seoul the opportunity also to stimulate a recommitment to the Millennium Development Goals (MDGs) as the global agreed framework for development leading up to 2015 (Park 2010). The 2011 Busan HLF-4 on aid effectiveness was noteworthy for its inclusive nature; more than 2,000 government, civil society, and business representatives, from both developed and developing countries, participated in discussions on the current global development assistance situation (Olbrich and Shim 2012, 2). The August 2012 "Development Partnership of Korea" led to a Memorandum of Understanding (MOU) "signed by a broad range of stakeholders, including the Ministry of Foreign Affairs and Trade, KOICA, the Korea NGO Council for Overseas Cooperation, the Federation of Korean Industries, the Korean Council for University Education, the Korea Association for International Development and Cooperation, the Global Compact Korea Network, and the UN Academic Impact" to identify existing projects where such collaboration can make a difference (Watson 2013, 232-233).

At the same time, the Republic of Korea has been at the forefront of "green growth" initiatives. President Lee Myung-bak founded the Global Green Growth Institute (GGGI) in 2010, and this was later converted into an international 
treaty-based organization in 2012 at the Rio+20 Summit. In January of the same year, the GGGI, the OECD, the United Nations Environment Programme (UNEP), and the World Bank signed an MOU to formally launch the Green Growth Knowledge Platform (GGKP) to enhance and expand efforts to identify and address major knowledge gaps in green growth theory and practice, and to help countries design and implement policies to move towards a green economy. The UN Sustainable Development Goals (UNSDGs) and their evolution through successive international fora, represent opportunities for Korea to continue its previously successful niche diplomacy and agenda setting in these fields.

In the security field, due to geopolitical constraints, the ROK is unable to perform the neutral or brokering role of traditional middle powers (Kalinowski and Cho 2012, 244). Thus, Seoul's major policy forays and initiatives in the security realm have tended to revolve around the intersection of security and development, and how this intersection contributes to peacebuilding. Again, Seoul's bilateral policy-making in this area has had, at most, limited success. These include approaches to North Korea, such as the Kaesong Industrial Complex (KIC), the "Sunshine Policy," and elements of the Park administration's "Trustpolitik." All of these initiatives were subject to politicization by the actors, and ultimately did little to build trust, let alone contribute to peacebuilding. Bilateral initiatives in the security realm are too obviously strategic in terms of attempting, first and foremost, to promote the national interests of the ROK. Emphasizing the need for Korean unification as a prerequisite for peace in the region would seem to be a case of putting the cart before the horse. In fact, North Korea is the only country in the world in which South Korea does have neoimperial baggage, and to which the ROK poses an existential threat.

At the official launch of the ROK's new Act on Public Diplomacy in August 2016, the old, soft power interpretations of public diplomacy and middlepowerism remained in the fore. For instance, Duk-min Yun, Chancellor of the Korea National Diplomatic Academy claimed that "now is the time for Korea's public diplomacy to take a leap forward, given the significance of soft power in determining a middle power's diplomatic sway" (Korea Herald 2016). An official emphasis on soft power and winning hearts and minds, and promoting unification, whether only with regard to North Korea or in general, means that there is a danger ROK initiatives will be written off as spin, worse, as propaganda, or even hostile intervention. One irony of soft power is that "the theory emphasizes the importance of attraction in world affairs but presents that attraction as a mechanism for getting one's way, which is potentially an unattractive objective" (Cull 2006).

The ROK does, however, play an active role in multilateral UN human security mechanisms such as the Office for the Coordination of Humanitarian Affairs (OCHA), which is the main UN body designed to strengthen the UN's response to both complex emergencies and natural disasters. The ROK 
government has also officially expressed its support for the responsibility to protect $(\mathrm{R} 2 \mathrm{P})$ principles. These roles and policies not only reflect an alternative strategic mission for the ROK, but also spill over into the realm of global governance and good international citizenship. The ROK supports all internationally agreed-upon humanitarian principles such as impartiality, neutrality, and independence, and applies them to foreign, security, and assistance policies.

As part of its efforts, Korea has made good progress towards ensuring better humanitarian donorship through a legislative framework for its humanitarian action, and a commitment to increase its humanitarian aid. In March 2007, Korea enacted the Overseas Emergency Relief Act designed to allow the Korean government to provide more effective and prompt overseas emergency relief in order to play a greater role in the concerted efforts of the global community towards disaster management. Korea has been part of the UN Disaster Assessment and Coordination (UNDAC) teams since 2003 and the International Search and Rescue Advisory Group (INSARAG) since 1999. Since Korea specializes in search and rescue efforts, it has participated in the OCHA-administered Asia Pacific Humanitarian Partnership (APHP) since its establishment in 2004. Korea provided the largest contingent of forces for relief and reconstruction efforts in the Philippines after the devastation wrought by Typhoon Haiyan in November 2013. Furthermore, the ROK forces were committed to the mission for far longer than those of any other contributing nation-two full six month tours of duty rather than just helping with the emergency relief mission in the immediate aftermath of the disaster (Arcala Hall 2016).

The most visible contribution as a good global citizen has come in the ROK involvement in peacekeeping and other UN missions. Despite a heavy emphasis on the promotion of national interest in Korean international policy-making, nevertheless, one area in which normative considerations do structure ROK international policy formation is through what has become known as the "paying back syndrome" wherein Koreans believe that it is their "moral duty to help those who are caught in armed conflict" in return for the international assistance the country received during the Korean War (Hong 2009, 24). Such sentiments were also expressed by Sung Joo Han, former minister of Foreign Affairs, and Min Koo Han, former Minister of National Defense at a recent conference on international peacekeeping (Han, S.J. 2014; Han, M.K. 2014).

"Paying back" also of course applies to government and public support for increasing Korean ODA. Iain Watson (2013, 224-225) has identified "a national consensus that crosses party lines and which is often based on Korean exceptionalism and patriotism ... broken down into Seoul 'paying back' those countries that had helped Korea" with domestic public support for ODA linked to a "South Korean sense of honour, fairness and justice to foreigners." While the concept may be more prevalent among policy elites and older generations, 
and rather abstract for the youth, nevertheless, there remains a strong impetus for humanitarian participation and activism among young Koreans, as has been demonstrated in high levels of domestic and international volunteerism (Howe 2014, 56-58), as well as participation in protests.

The ROK acceded to membership of the UN in 1991, and has grown from being the host of the largest UN enforcement operation to date, to being a major contributor to international peacekeeping operations. For Eun-Sook Chung (2010, 101), Seoul's support for UN PKOs "conveys the message of reciprocating international assistance it received after 1945, and it also demonstrates the nation's will and capabilities to contribute to the maintenance of peace in the international community." Furthermore, for Sangtu Ko (2012, 288), peacekeeping operations represent the one field where Korea truly aspires to middle power activism. While still modest, Korea's troop contributions are already substantial when compared with other medium-size country members of the OECD such as Japan, the United Kingdom, or Germany. Currently, the ROK ranks thirty-ninth in military and police contributors to UN operations with just over 600 currently active personnel (UN 2015).

Furthermore, senior political and military leaders have repeatedly iterated the intent to expand the ROK's role. President Lee Myung-bak stated in 2009, at an event commemorating national independence, that he would "raise the value of the national brand through optimal use of two instruments, namely ODA and PKO” (Ko 2012, 296). The 2010 Defense White Paper announced a plan steadily to expand Korea's participation in international peacekeeping operations. In July 2013, the Joint Chiefs of Staff talked of further beefing up Korea's presence in international PKOs (Kang 2013). Also in 2013, in order to improve the functioning of Korean peacekeeping operations, the government increased the staff of the PKO Center, and relocated it from the ROK Joint Staff College to the National Defense University. The PKO center provides pre-deployment education and training to military and police personnel, writes up the "after action" reports to assess the effectiveness of the unit, and gathers any lessons learned for future missions, while also participating in exchange programs with $\mathrm{PKO}$ units from other countries to improve training and coordination (Roehrig 2013, 639). These aspirations have started to be reflected in practice.

Since the dispatch of its first peacekeepers, the Ever Green Unit, which constituted part of the 1993 United Nations Operation in Somalia (UNOSOM) II peacekeeping mission, the ROK has deployed some 40,000 globally. Korea also dispatched personnel to the United Nations Mission for the Referendum in Western Sahara (MINURSO); the United Nations Angola Verification Mission III (UNAVEM III); the United Nations Military Observer Group in India and Pakistan (UNMOGIP); the United Nations Observer Mission in Georgia (UNOMIG); the United Nations Mission in Liberia (UNMIL); the United Nations Assistance Mission in Afghanistan (UNAMA); United Nations 
Integrated Mission in Timor-Leste (UNMIT); the United Nations Mission in Nepal (UNMIN); the United Nations Interim Force in Lebanon (UNIFIL); the United Nations Stabilization Mission in Haiti (MINUSTAH); the United Nations Operation in Côte d'Ivoire (UNOCI); the United Nations Mission in Darfur (UNAMID); and the United Nations Mission in South Sudan (UNMISS) (Howe and Kondoch 2014, 149).

In general, Korea receives high marks for its performance in UN peacekeeping operations and it is well suited for peacekeeping as a middle power because of its geographical and political distance to many conflicts in the world. Peacekeeping also helps to improve Korea's image as a responsible middle power in international relations and it allows Korea "to differentiate itself in a proactive manner from its Northeast Asian neighbors China and Japan” (Hwang 2012, 184). Further, Korean motivations include securing international support vis-àvis North Korea; keeping up with the neighbors China and Japan; and, in the past, supporting the Korean-born Secretary General of the UN (Lee and Park 2014, 4).

Korea is not alone among regional powers looking to play an expanded role in the non-traditional security cooperation operating environment. Despite recent legislation enabling a more pro-active stance, in traditional security terms, Japan has been and continues to be "reactive" with regards to the United States, and, at a societal level, has not fully embraced peacekeeping, peace-building, and humanitarian intervention initiatives under the R2P. Nevertheless, ODA and other forms of international assistance can be viewed not only as an area of autonomous Japanese foreign policy formation that defies the reactivist hypothesis, but even as an alternative form of security policy formation. Non-military assistance continues to be the means by which the Japanese government promotes the comprehensive human security agenda internationally simultaneously with its national interest. Even China, long seen as hostile to collective security institutions, has, in the last ten years, become the major troop contributor to UN PKOs among the P5, with a twenty-fold increase since the early 2000s. Although China has, in general, not participated in robust operations, in 2013 Beijing decided to send combat forces to the United Nations Multidimensional Integrated Stabilization Mission in Mali (MINUSMA) (Howe and Kondoch 2014, 138).

From a soft power or strategic perspective, clearly competing actors in the same arena can pose a visibility challenge, and undermine the uniqueness of a policy niche. From a "network" perspective, however, having other countries pursuing humanitarian or normative diplomatic agendas is not zero-sum. There is a potential for collective identification, and reinforcement of international perceptions of actors in East Asia, as belonging to the "go-to" region for nontraditional or humanitarian security issues. This would make a welcome change from perceptions of the region as one of the most dangerous, state-centric, power-political, or "realist" orientated in the world. It would likewise provide an 
avenue for security cooperation in a region which has been noticeable for its lack of formal institutions or international organizations, thereby spilling over into other realms of cooperation and peacebuilding. Here, Korea can actually gain by association with the initiatives of others, and has the potential to even be the agenda-setting first among equals, given its comparative lack of baggage, even if China and Japan have greater power resources.

\section{Conclusion}

Korea is a middle power with somewhat middling access to resources. It cannot aspire to great-powerhood in that it cannot influence international affairs across all dimensions, but is far better endowed than many small or weak states. Korea often pursues strategies appropriate to middle-powerism (especially in the fields of development, education, and non-traditional and humanitarian security perspectives), and has a middling ability to impact the external operating environment (either unilaterally through the soft power pursuit of influence and niche diplomacy, or as part of multilateral agenda-setting, conference, and network diplomacy). Middle power Korea is eminently suited to playing a major regional role in the promotion of peace and economic development. Furthermore, this role has been identified as a key area of Korean niche and public diplomacy, and thereby an extension of national interest, middle power activism, and soft power projection.

Despite perhaps less than completely altruistic motivations, given the humanitarian policy areas identified for national diplomatic focus, there is tremendous potential for others in the region to be aided by Korean initiatives and agenda-setting. Perhaps this could be termed "collateral benefit" or a happy coincidence of national interest of the middle power actor and the needs of vulnerable individuals and groups, as well as the wider regional security and development operating environment (Howe 2013). Indeed, because it is in the ROK's national interest to help others, they may be more committed to doing so. In addition, this international role has been internalized across the political spectrum as part of the paying back syndrome. Thus commitment to the role, and even its expansion, is likely to endure.

Nevertheless, this article has identified numerous short-comings in the "Korean Model" and in the government's attempts to promote it. It may, ultimately, be more beneficial to both Korea and the international community if the ROK were more of a team player, collaborating in networks of global governance and good citizenship. Multilateralism encourages the formation, maintenance, and use of networks of social, cultural, political, and economic connections within and between actors as a method of persuasion in public diplomacy (Rudderham 2008, 6). The role of middle powers is amplified 
under the contemporary architecture of global governance featuring multiple channels for expression such as the UN, OECD, World Bank, G20, World Trade Organization (WTO), and the proliferation of regional organizations (except of course in East Asia). It is possible for a country to do well by doing good. A country, or a region, (such as normative-acting Europe or the Nordic region) "can become known, admired, and also rewarded for its 'goodness'-which becomes a kind of niche in itself" (Henrikson 2005, 68).

\section{Acknowledgments}

The author would like to acknowledge the support of a research grant from Ewha Womans University on human security in the Age of the Anthropocene [grant number 1-2017-0756-001-1].

\section{References}

Arcala Hall, Rosalie. 2016. Interviewed by author in Seoul, May 30.

Bradford, Colin. 2015. "South Korea as a Middle Power in Global Governance: 'Punching Above Its Weight' Based on National Assets and Dynamic Trajectory." In MiddlePower Korea: Contributions to the Global Agenda, eds. Colin Bradford, Toby Dalton, Brendan Howe, Jill Kosch O’Donnell, Andrew O’Neil, and Scott Snyder, 8-20. Washington, D.C.: Council on Foreign Relations.

Calder, Kent. 1988. "Japanese foreign economic policy formation: Explaining the reactive state." World Politics 40 (4): 517-541.

Choi, Jin-wook. 2010. "From a Recipient to a Donor State: Achievements and Challenges of Korea's ODA." International Review of Public Administration 15 (3): 37-51.

Chun, Hong-min, Elijah Munyi, and Heejin Lee. 2010. "South Korea as an Emerging Donor: Challenges and Changes on Its Entering OECD/DAC." Journal of International Development 22 (6): 788-802.

Chung, Eun-sook. 2010. "Korea's Law on UNPKO and Its Role in International Peacekeeping Missions." Korea Focus 18 (2): 98-102.

Cline, Ray. 1977. World Power Assessment: A Calculus of Strategic Drift. Boulder: Westview Press.

Cull, Nicholas. 2006. "'Public Diplomacy’ Before Gullion: The Evolution of a Phrase." USC Center on Public Diplomacy, CPD Blog, April 18. http://uscpublicdiplomacy. org/blog/060418_public_diplomacy_before_gullion_the_evolution_of_a_phrase (accessed August 12, 2017).

Darracq, Vincent, and Daragh Neville. 2014. "South Korea's Engagement in Sub-Saharan Africa Fortune, Fuel and Frontier Markets." Chatham House Research Paper, October 20. https://www.chathamhouse.org/publication/south-korea\%E2\%80\%99sengagement-sub-saharan-africa-fortune-fuel-and-frontier-markets (accessed August 12 , 2017). 
Han, Min-Koo. 2014. "Keynote Speech." Speech given at the PKO International Conference: New Challenges and Future Prospects of Peacekeeping Operations, Sookmyung Women's University, Seoul, November 13.

Han, Sun-Joo. 2014. "Congratulatory Remarks." Speech given at the PKO International Conference: New Challenges and Future Prospects of Peacekeeping Operations, Sookmyung Women's University, Seoul, November 13.

Haas, Ernst. 1964. Beyond the Nation-state: Functionalism and International Organization. Stanford: Stanford University Press.

Heiss, Klaus P., Klaus Knorr, and Oskar Morgenstern. 1973. Long Term Projections of Power: Political, Economic, and Military Forecasting. Cambridge, MA: Ballinger Pub. Co.

Henrikson, Alan. 2005. "Niche Diplomacy in the World Public Arena: the Global 'Corners' of Canada and Norway." In The New Public Diplomacy: Soft Power in International Relations, ed. Jan Melissen, 67-87. Basingstoke: Palgrave Macmillan.

Hocking, Brian. 2005. "Rethinking the 'New' Public Diplomacy." In The New Public Diplomacy: Soft Power in International Relations, ed. Jan Melissen, 28-46. Basingstoke: Palgrave Macmillan.

Hong, Kyudok. 2009. "South Korean Approaches to Peacekeeping and Peacebuilding: Lessons Learned and Challenges Ahead." The Journal of East Asian Affairs 23 (1): 23 46.

Howe, Brendan. 2013. The Protection and Promotion of Human Security in East Asia. Basingstoke: Palgrave Macmillan.

Howe, Brendan, ed. 2014. Korea in the World: Promoting Mutual Understanding and Global Partnerships. Seoul: Ministry of Foreign Affairs.

Howe, Brendan, and Boris Kondoch. 2014. "Northeast Asian Perspectives on UN Peacekeeping: China, Japan, Korea." Journal of International Peacekeeping 18 (3-4): 133-153.

Hwang, Balbina. 2012. "Peacekeeping." In The US-South Korea Alliance: Meeting New Security Challenges, ed. Scott Snyder. Boulder: Lynne Rienner.

ITUC (International Trade Union Congress). 2015. "Global Rights Index." https://www. ituc-csi.org/IMG/pdf/survey_global_rights_index_2015_en.pdf (accessed August 12, 2017).

Kalinowski, Thomas, and Hyekyung Cho. 2012. "Korea’s Search for a Global Role between Hard Economic Interests and Soft Power." European Journal of Development Research 24: $242-260$.

Kang, Seung-woo. 2013. "Korea Beefing up Presence in PKO.” The Korea Times, July 11. https://www.koreatimes.co.kr/www/news/nation/2013/07/116_139642.html (accessed August 12, 2017).

Kiai, Maina. 2016. "Statement by the United Nations Special Rapporteur on the Rights to Freedom of Peaceful Assembly and of Association at the Conclusion of His Visit to the Republic of Korea." January 29. http://www.ohchr.org/EN/NewsEvents/Pages/ DisplayNews.aspx?NewsID=16998\&LangID=E (accessed August 12, 2017).

Kim, Eun Mee. 1997. Big Business, Strong State: Collusion and Conflict in South Korean Development, 1960-1990. New York: State University of New York Press.

Kim, Eun Mee, Pil Ho Kim, and Jinkyung Kim. 2013. "From Development to Development Cooperation: Foreign Aid, Country Ownership, and the Developmental State in 
South Korea." The Pacific Review 26 (3): 313-336.

Kim, Soyeon. 2011. "Bridging Troubled Worlds? An Analysis of the Ethical Case for South Korean Aid." Journal of International Development 23: 802-822.

Ko, Sangtu. 2012. "Korea’s Middle Power Activism and Peacekeeping Operations." Asia Europe Journal 10: 287-299.

Koo, Hagen. 2014. “Inequality in South Korea.” East Asia Forum, July 1. http://www. eastasiaforum.org/2014/07/01/inequality-in-south-korea/ (accessed August 12, 2017).

Korea Herald. 2016. "New Law to Boost Public Diplomacy." August 4.

KSP (Knowledge Sharing Program). 2013. "Policy Consultation: Bilateral KSP." http://www. ksp.go.kr/pillars/policymain.jsp. (accessed August 12, 2017).

Lee, Jong-wha. 1997. "Economic Growth and Human Development in the Republic of Korea, 1945-1992." UNDP, Occasional Paper 24. http://hdr.undp.org/en/content/ economic-growth-and-human-development-republic-korea-1945-1992 (accessed August 12, 2017).

Lee, Anselmo. 2012. "Post-Busan and New Paradigm for International Development Cooperation." Presentation given on July 22. https://www.kdevelopedia.org/resource/ view/04201408040133449.do\#.VKkiZeamqpo (accessed August 12, 2017).

Lee, Seungjoo. 2014. "South Korea’s Middle Power Diplomacy: Multilayered World Order and The Case of Development Cooperation Policy." EAI MPDI Working Paper, October. https://www.eai.or.kr/data/bbs/eng_report/2014102816225492.pdf (accessed August 12, 2017).

Lee, Shin-hwa, and Joon Sung Park. 2014. Contributor Profile: South Korea (Seoul: Korea University) https://s3.amazonaws.com/ipi-pdf-document-store/ppp-profiles/asia/ipipub-ppp-Korea.pdf 1-8 (accessed August 12, 2017).

Ma, Young Sam, Jung-he Song, and Dewey E. Moore. 2012. "Korea's Public Diplomacy: A New Initiative for the Future." Asan Policy Institute Issue Brief \#39, December 20. http://en.asaninst.org/contents/issue-brief-no-39-koreas-public-diplomacy-a-newinitiative-for-the-future/ (accessed August 12, 2017).

Mitrany, David. 1976. The Functional Theory of Politics. New York: St. Martin's Press.

MOFA (Ministry of Foreign Affairs). 2016. "Overview." http://www.mofa.go.kr/ENG/ policy/culture/overview/index.jsp?menu=m_20_150_10 (accessed August 12, 2017).

Ney, Jose. 2008. "Democracy in South Korea: Mature Society Versus Immature System" Ethics in Action 2 (4). http://www.ethicsinaction.asia/archive/2008-ethics-in-action/ vol.-2-no.-4-august-2008/democracy-in-south-korea-mature-society-versus (accessed August 12, 2017).

Nye, Joseph. 1990. Bound to Lead: The Changing Nature of American Power. New York: Basic Books.

Nye, Joseph. 2004. Soft Power: The Means to Success in World Politics. New York: Public Affairs.

ODA Korea. 2013. "History of Korea’s ODA." http://www.odakorea.go.kr/eng.overview. History.do (accessed August 12, 2017).

ODA Korea. 2014. "Korea's ODA White paper: Opening a New Era of Happiness for All Humanity." http://www.odakorea.go.kr/hz.blltn.pnrSl.do?bltn_seq=5\&sys_cd=\&brd_ seq=22\&targetRow=\&blltn_div=oda\&keyword_top $=\&$ searchKey $=01 \&$ keyword $=$ (accessed August 12, 2017).

OECD (Organisation for Economic Cooperation and Development). 2012. "Korea: 
Development Assistance Committee (DAC) Peer Review 2012." http://www.oecd.org/ dac/peerreviewsofdacmembers/Korea\%20CRC\%20-\%20FINAL\%2021\%20JAN.pdf (accessed August 12, 2017).

OECD (Organisation for Economic Cooperation and Development) Query Wizard. 2013. http://stats.oecd.org/qwids/ (accessed August 12, 2017).

Office of the President. 2009. Global Korea: The National Security Strategy of the Republic of Korea. Seoul: Cheong Wa Dae.

Olbrich, Philip, and David Shim. 2012. "South Korea as a Global Actor: International Contributions to Development and Security." German Institute of Global and Area Studies, GIGA Focus \#2. http://www.giga-hamburg.de/en/system/files/publications/ gf_international_1202.pdf (accessed August 12, 2017).

Park, Kang Ho. 2010. “Korea’s Role in Global Development.” Brookings East Asia Commentary Number 36, February. http://www.brookings.edu/research/opinions/ 2010/02/09-korea-global-development (accessed August 12, 2017).

Park, Sung-Hoon. 2014. "South Korea and the European Union: A Promising Partnership for Development Cooperation?" European Strategic Partnerships Observatory, Policy Brief 15, November. http://fride.org/download/PB_15_South_Korea_and_the_ European_Union.pdf (accessed August 12, 2017).

Pillay, Pundy. 2010. Linking Higher Education and Economic Development: Implications for Africa from Three Successful Systems. Wynberg: Center for Higher Education Transformation (CHET).

Roehrig, Terrence. 2013. "South Korea, Foreign Aid, and UN Peacekeeping: Contributing to International Peace and Security as a Middle Power." Korea Observer 44 (4): 623645.

Rudderham, M.A. 2008. "Middle Power Pull: Can Middle Powers use Public Diplomacy to Ameliorate the Image of the West?" York Centre for International Security Studies Working Paper 46, February. http://yciss.info.yorku.ca/files/2012/06/WP46Rudderham.pdf (accessed August 12, 2017).

Singer, J. David, and Paul F. Diehl, eds. 1990. Measuring the Correlates of War. Ann Arbor: The University of Michigan Press.

Stoll, Richard J., and Michael D. Ware. 1989. Power in World Politics. Boulder: Lynne Rienner Publishers.

Suh, Jae-Jung, and Jinkyung Kim. 2014. "Aid to Build Governance in a Fragile State: Foreign Assistance to a Post-Conflict South Korea." In Post-Conflict Development in East Asia, ed. Brendan M. Howe. Farnham: Ashgate Publishing.

Tellis, Ashley J., Janice Bially, Christopher Layne, and Melissa McPherson. 2000. Measuring Power in the Postindustrial Age. Santa Monica: RAND.

The Economist. 2012. "South Korea's Influence in Asia: This Year's Model." February 18. http://www.economist.com/node/21547865 (accessed August 12, 2017).

UN (United Nations). 2015. "Ranking of Military and Police Contributions to UN Operations." http://www.un.org/en/peacekeeping/contributors/2015/mar15_2.pdf (accessed August 12, 2017).

Vom Haua, James Scott Matthias, and David Hulme. 2012. "Beyond the BRICs: Alternative Strategies of Influence in the Global Politics of Development.” European Journal of Development Research 24 (2): 187-204.

Watson, Iain. 2013. "Beyond the Aid Trap for Emerging Donors: Private and Public 
Partnerships in South Korea's Official Development Assistance (ODA) Strategy." Journal of Comparative Asian Development 12 (2): 212-244.

Whitehead, Laurence. 1996. "Three International Dimensions of Democratization.” In The International Dimensions of Democratization: Europe and the Americas, ed. Laurence Whitehead. New York: Oxford University Press.

World Friends Korea. 2016. http://www.worldfriendskorea.or.kr/eng/historyInfo/eng.intro. history/list.do (accessed August 12, 2017).

Brendan M. Howe is a Professor and former Associate Dean of the Graduate School of International Studies, Ewha Womans University, where he has worked since 2001. His ongoing research agendas focus on traditional and non-traditional security in East Asia, human security, democratic governance, public diplomacy, and post-crisis development. Major recent works include Democratic Governance in Northeast Asia (2015); Post-Conflict Development in East Asia (2014); The Protection and Promotion of Human Security in East Asia (2013); and Northeast Asian Perspectives on the Legality and Legitimacy of the Use of Force (2013). E-mail: howeb@ewha.ac.kr; bmg.howe@gmail.com

Submitted: September 8, 2016; Revised: December 5, 2016; Accepted: December 15, 2016 